Lauren Bogue, MS

Sindhu Ramchandren, MD, MS

Neurol Genet

2016;2:e103; doi: 10.1212 NXG.0000000000000103
See editorial

\section{OUTDATED RISK ASSESSMENT IN A FAMILY WITH DUCHENNE DYSTROPHY: IMPLICATIONS FOR DUTY TO REASSESS \\ OPEN}

Carrier risk assessment for Duchenne muscular dystrophy (DMD) is necessary to counsel women at risks of developing cardiomyopathy and having a child with DMD. Comprehensive molecular testing for dystrophin gene mutations has only been available since $2003^{1}$; women counseled earlier have outdated risk assessments. We present a 5 -generation family in whom results of familial mutation testing for DMD newly identified 10 obligate carriers and 28 women at risk to be carriers for DMD.

Case descriptions. The proband presented to us at 5 years of age for evaluation of weakness and motor developmental delay. His examination revealed low muscle tone with calf atrophy; strength was $4 / 5$ in the Medical Research Council scale in his deltoids and hip flexors. He had a lordotic gait with inability to run and a positive Gower maneuver. A 5 -generation pedigree was obtained (figure). Individual III-10, the proband's grandmother, provided the history and identified V-1 as a patient at our center, who had been diagnosed with DMD. V-1 is the proband's third cousin through a lineage comprising women. Individuals III-1, III-18, and IV-7 were noted to have died at ages 21,22, and 19, respectively, of DMD. At the time the family history was obtained, II9 and III-10 reported that they were not carriers of DMD. III-10 and her sister, III-11, were tested in the 1980s and were told that they were "low carriers" for DMD, while III-3 was told that she was a "high carrier" for DMD; similar risk categorization has been used in the literature ${ }^{2}$ and may reflect the genetic counseling they were provided. This assessment led III-3 to decide not to have more children.

Review of V-1's records confirmed that he had a novel $D M D$ splice site mutation, c.8669-2A $>\mathrm{T}$, which is predicted to disrupt the exon 59 splice acceptor site. Creatine kinase (CK) level of the proband was elevated at 21,837 IU/L, and genetic testing confirmed the same splice site mutation identified for $\mathrm{V}-1$. The dystrophinopathy phenotype, early onset, and ages of death indicated that the splice site mutation c.8669-2A $>\mathrm{T}$ was causative for DMD. Seven new diagnoses of obligate carriers, including III-10, were identified via the lineage of women that connected the proband and $\mathrm{V}-1$, extending back to the patients' common great-great-grandmother. Three additional obligate carriers, including II-9, were identified based on the pattern of affected males. Twenty-eight other women in the family were identified as at risk to be carriers, including III-11.

Discussion. Our objective was to highlight the importance of reassessing individuals who received their initial DMD risk assessment prior to 2003. Women who know that they are carriers for DMD use this information to make choices about future pregnancies or continuing current pregnancies. ${ }^{2} \mathrm{Car}-$ riers require early, lifelong cardiac screening because of increased risk to develop cardiomyopathy. ${ }^{3}$ With the exception of women who can be assigned an obligate carrier status based on affected family members, direct molecular testing for the familial mutation is the only way to determine an individual's carrier status.

Understanding the historical timeline of DMD testing is helpful in identifying those who need reassessments. From 1960 through 1980, risk assessments were made using a combination of pedigree analysis, serum CK, and muscle biopsy. ${ }^{4}$ While these frequently identified carriers with a low false-positive rate, confirmation of negative carrier status was not possible because not all demonstrated abnormalities. Molecular analysis for DMD began in the 1980s with haplotype analysis, using restriction fragment length polymorphisms linked to the disease locus. ${ }^{5}$ However, this method could not predict disease/carrier status with certainty because of the chance for meiotic recombination. Following complete cloning of the complementary DNA for DMD in 1987, direct tests for common deletions became available. ${ }^{6}$ Dystrophin sequencing, which was required to detect the splice site mutation in our family, became clinically available in 2003. ${ }^{1}$ Thus, careful probing can reveal whether the first diagnosis in the family took place before the availability of the testing method specific to the familial mutation, as with our family. 


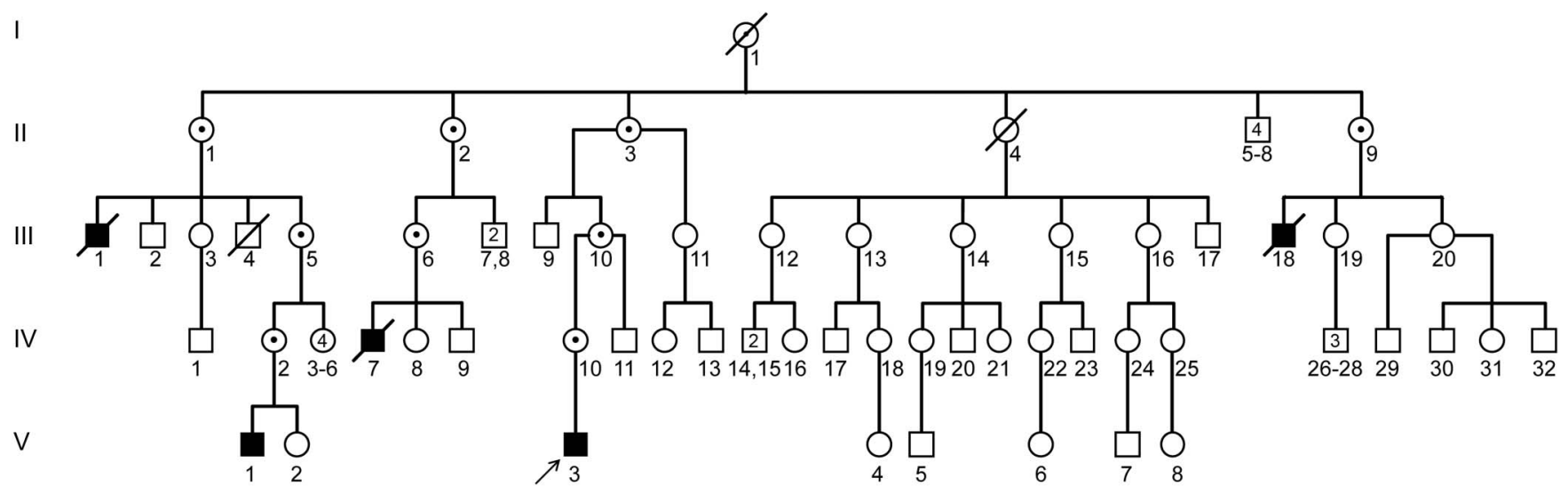

The proband is indicated by an arrow. Shaded individuals are those affected by Duchenne muscular dystrophy. Obligate carrier status for Duchenne is denoted by a dot within the individual's symbol. Within the text, individuals are identified by their roman numeral generation number followed by the number of individuals; reading from left to right, this identifies their location within the generation. These numbers are inclusive of the total number of individuals in grouped sibships, which are denoted by an individual symbol containing a number.

Outdated risk assessments are not unique to neurologic genetic disorders; given advances in genetic testing technology over the last decade alone, patients with previously negative risk assessments may benefit from periodic reassessment to meet contemporary standards. As summarized in a recent review of 61 articles on the topic of "Duty to Reassess," most patients favor being recontacted; physicians favor recontacting in principle, but note practical barriers such as lack of infrastructure to track former patients and their tests. ${ }^{7}$ We recommend that healthcare professionals confirm the timing and method of genetic diagnoses, specifically for DMD families reporting negative carrier risk assessments from prior to 2003.

From the Parent Project Muscular Dystrophy (L.B.), Hackensack, NJ; and Department of Neurology (L.B., S.R.), University of Michigan, Ann Arbor.

Author contributions: Ms. Bogue: clinical data acquisition, analysis and interpretation of genetic data, and manuscript preparation. Dr. Ramchandren: clinical data acquisition and interpretation and manuscript revision.

Study funding: Dr. Ramchandren is funded by the NIH (National Institute of Neurological Disorders and Stroke K23-NS072279).

Disclosure: Dr. Bogue reports no disclosures. Dr. Ramchandren has received research support from NIH. Go to Neurology. org/ng for full disclosure forms. The Article Processing Charge was paid by the authors.

This is an open access article distributed under the terms of the Creative Commons Attribution-NonCommercial-NoDerivatives License 4.0 (CC BY-NC-ND), which permits downloading and sharing the work provided it is properly cited. The work cannot be changed in any way or used commercially.

Received June 20, 2016. Accepted in final form August 3, 2016.

Correspondence to Dr.Ramchandren: sindhur@umich.edu

1. Flanigan KM, von Niederhausern A, Dunn DM, Alder J, Mendell JR, Weiss RB. Rapid direct sequence analysis of the dystrophin gene. Am J Hum Genet 2003;72:931-939.

2. Emery AE, Watt MS, Clack ER. The effects of genetic counselling in Duchenne muscular dystrophy. Clin Genet 1972;3:147-150.

3. American Academy of Pediatrics Section on Cardiology and Cardiac Surgery. Cardiovascular health supervision for individuals affected by Duchenne or Becker muscular dystrophy. Pediatrics 2005;116:1569-1573.

4. Emery AE. Muscle histology in carriers of Duchenne muscular dystrophy. J Med Genet 1965;2:1-7.

5. Hofker MH, Wapenaar MC, Goor N, Bakker E, van Ommen GJ, Pearson PL. Isolation of probes detecting restriction fragment length polymorphisms from $\mathrm{X}$ chromosomespecific libraries: potential use for diagnosis of Duchenne muscular dystrophy. Hum Genet 1985;70:148-156.

6. Koenig M, Hoffman EP, Bertelson CJ, Monaco AP, Feener C, Kunkel LM. Complete cloning of the Duchenne muscular dystrophy (DMD) cDNA and preliminary genomic organization of the DMD gene in normal and affected individuals. Cell 1987;50:509-517.

7. Otten E, Plantinga M, Birnie E, et al. Is there a duty to recontact in light of new genetic technologies? A systematic review of the literature. Genet Med 2015;17:668-678. 


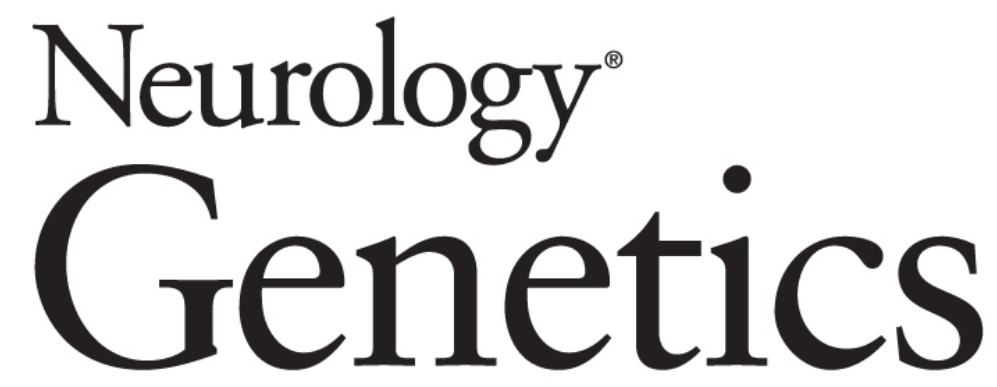

Outdated risk assessment in a family with Duchenne dystrophy: Implications for duty to reassess

Lauren Bogue and Sindhu Ramchandren

Neurol Genet 2016;2;

DOI 10.1212/NXG.0000000000000103

This information is current as of October 5, 2016

Neurol Genet is an official journal of the American Academy of Neurology. Published since April 2015, it is an open-access, online-only, continuous publication journal. Copyright ( 2016 American Academy of Neurology. All rights reserved. Online ISSN: 2376-7839.

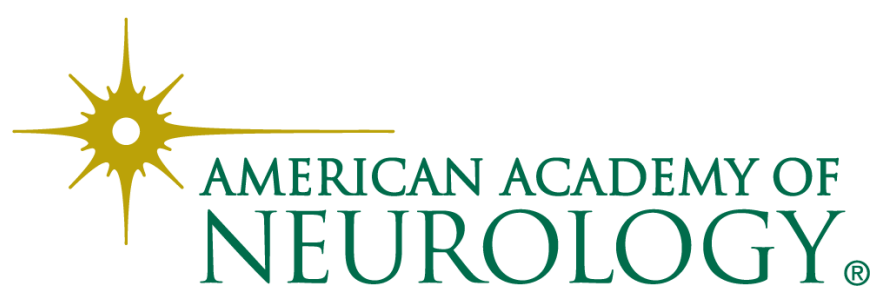




\section{Updated Information \& Services}

References

Citations

Subspecialty Collections

Permissions \& Licensing

Reprints including high resolution figures, can be found at: http://ng.neurology.org/content/2/5/e103.full.html

This article cites 7 articles, 1 of which you can access for free at: http://ng.neurology.org/content/2/5/e103.full.html\#\#ref-list-1

This article has been cited by 2 HighWire-hosted articles: http://ng.neurology.org/content/2/5/e103.full.html\#\#otherarticles

This article, along with others on similar topics, appears in the following collection(s):

\section{All Ethics in Neurology/Legal issues}

http://ng.neurology.org//cgi/collection/all_ethics_in_neurology_legal_i ssues

All Genetics

http://ng.neurology.org//cgi/collection/all_genetics

Muscle disease

http://ng.neurology.org//cgi/collection/muscle_disease

Information about reproducing this article in parts (figures,tables) or in its entirety can be found online at:

http://ng.neurology.org/misc/about.xhtml\#permissions

Information about ordering reprints can be found online: http://ng.neurology.org/misc/addir.xhtml\#reprintsus

Neurol Genet is an official journal of the American Academy of Neurology. Published since April 2015, it is an open-access, online-only, continuous publication journal. Copyright ( 2016 American Academy of Neurology. All rights reserved. Online ISSN: 2376-7839.

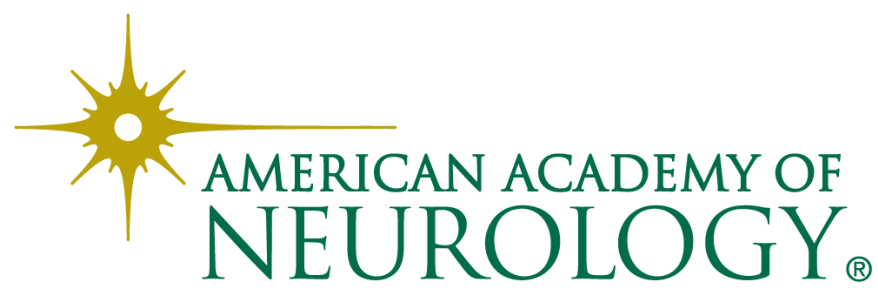

